\title{
Financeirização do território e novos nexos entre pobreza e consumo na metrópole de Sáo Paulo
}

\author{
Marina Montenegro. Universidade de São Paulo, São Paulo, Brasil. \\ Fabio Contel. Universidade de São Paulo, São Paulo, Brasil.
}

RESUMo | A financeirização tornou-se um dos componentes mais dinâmicos do capitalismo contemporâneo, implicando transformaçôes expressivas na circulação global da riqueza, mas também na organização dos territórios nacionais e na vida cotidiana das populaçóes urbanas. Os novos nexos financeiros existentes entre a urbanização brasileira e a vida dos agentes econômicos atingem parcelas cada vez maiores da população pobre, assim como áreas menos valorizadas e/ou periféricas dos tecidos urbanos. No Brasil, esta financeirização conforma uma situação paradoxal, na qual a expansão do consumo e da financeirização entre as camadas de baixa renda se combina à ampliação da pobreza. Através de uma ampla revisão bibliográfica, pesquisa documental e de campo, identificamos como se dão os dinamismos desta nova pobreza que se configura na metrópole de São Paulo, atentando especificamente às transformaçôes das práticas de consumo entre a população de baixa renda assim como à nova topologia de grandes redes comerciais e de serviços.

PALAVRAS-CHAVE | pobreza, consumo, periferia urbana.

ABSTRACT | Financialization became one of the most dynamic components of contemporary capitalism, involving significant changes in the global circulation of wealth, but also in the organization of national territories and the daily life of urban populations. New financial links between the Brazilian urbanization and life of economic agents reach everlarger portions of poor people, as well as less valued andlor peripheral areas of the urban context. In Brazil, financialization conforms a paradoxical situation in which the expansion of consumption and financialization between the layers of low income combines to the expansion of poverty. Through an extensive literature review, and also documental and field research, we identify how to understand the dynamics of this new poverty that is configured in the metropolis of São Paulo, with special consideration to changes in consumer practices among the low-income population as well as the new topology of networks from large commercial and services companies.

KEYWORDs | poverty, consumption, urban periphery. 


\section{Introduçáo}

As transformações recentes na formação socioespacial brasileira, sob a hegemonia do capitalismo financeiro, implicam recomposiçôes sociais e territoriais que nos colocam novas indagaçóes sobre as atuais relaçóes entretecidas entre a pobreza, o consumo e as finanças nas cidades. Essas relações vêm sendo há tempos estudadas por diferentes intelectuais, como é o caso do geógrafo Milton Santos (1975). Para o autor, a economia urbana dos países periféricos pode ser entendida a partir da formação de dois circuitos de produção e consumo que se distinguem em função dos diversos graus de tecnologia, capital e organização assumidos pelas atividades urbanas. Quando esses são altos, trata-se do circuito superior, incluindo sua porção marginal; quando são baixos, trata-se do circuito inferior. Como o circuito superior da economia é mais intensivo em tecnologia e capitais, ele tende a concentrar a renda e a riqueza financeira produzida nas grandes cidades. Estas realidades sofrem transformaçóes espaciais derivadas de eventos de origem nacional e planetária, cujos rebatimentos provocam mudanças nas esferas do consumo e da produção (Silveira, 2014). Enquanto variável determinante do período, as finanças exercem atualmente um papel chave de vínculo entre o circuito inferior da economia, ou seja, da economia popular, e as grandes redes financeiras, varejistas e de serviços, representantes do circuito superior globalizado.

O processo de financeirização do território brasileiro (Santos e Silveira, 2001), ou ainda de hipercapilaridade das finanças (Contel, 2006, 2009), se dá com especial intensidade nas cidades, principalmente na metrópole de Sáo Paulo, rearranjando práticas sociais e conteúdos do território. Há, assim, uma indissociabilidade entre a atual configuração global do capitalismo, a história da formação socioespacial brasileira e as dinâmicas e formas urbanas (Silveira, 2011). Baseados neste partido de método e na teoria dos dois circuitos da economia urbana (Santos, 1975), buscamos desvendar certos nexos do processo de financeirizaçáo da pobreza em Sáo Paulo, atentando sobretudo às transformaçóes do consumo e do território em sua periferia.

A emergência de uma nova configuraçáo do capitalismo mundial a partir dos anos 1970 implicou a ascensão de um "regime de acumulação com dominância financeira” (Chesnais, 2005). A consolidação recente deste processo pode ser denominada "financeirização", termo crescentemente invocado nos debates sobre as dinâmicas do capitalismo contemporâneo. De acordo com Christophers (2015), a financeirização, junto à globalização e ao neoliberalismo, conformam um tripé analítico capaz de distinguir o capitalismo atual de períodos anteriores. Abrangendo um amplo processo de transformação econômica e cultural, a financeirização altera comportamentos e valores na economia, na política e na sociedade como um todo (Christopherson, Martin \& Pollard, 2013), renovando, consequentemente, os próprios conteúdos do território. Embora frequentemente empregado pela literatura anglo-saxã em análises da crise das hipotecas norte-americana do fim dos anos 2000, o potencial analítico do conceito abrange o processo mais amplo de reestruturação da economia sob regência da esfera financeira. Aalbers (2008) e Sokol (2013) propóem entender a financeirizaçáo como o deslocamento do capital dos circuitos primário, secundário e terciário para o circuito quaternário do capital, o qual não 
constitui um mercado de produção ou consumo, mas um mercado de especulação, ou ainda, um circuito de auto reprodução do capital. A financeirização coincide, nesta direção, com a afirmação do sistema financeiro enquanto uma esfera autônoma de acumulação e a decorrente reestruturação da economia global em benefício de agentes hegemônicos dos mercados financeiros (Lapavitsas \& Powell, 2013).

\section{Novos nexos entre pobreza e consumo}

Nos últimos anos, conjugaram-se no país; o avanço da urbanização e da metropolização, a redução dos índices de pobreza e a expansão do consumo (Neri, 2011; Pochmann, 2012; Instituto Brasileiro de Geografia e Estatística [iвGE]/Pesquisa Nacional por Amostra de Domicílios [PNAD], 2013). Ao longo das últimas décadas, o processo de urbanização da sociedade e do território brasileiro avançou rapidamente, visto que a população urbana passou de 55,92\% do seu total de habitantes em 1970 para 84\% em 2010 (IBGE, 2010), ano em que o país já reunia quinze cidades com mais de 1 milhão de habitantes, onde residiam $36,2 \%$ da população brasileira (IBGE, 2010). A metropolização, ou ainda, a crescente concentração populacional nas Regióes Metropolitanas constitui, assim, um processo característico da urbanizaçáo recente. Durante a última década ocorreu, ao mesmo passo, uma redução na proporção de pobres entre a população brasileira, a qual recuou de 38,6\% em 2001 para 20,6\% em 2011 (IBGE/PNAD, 2011). Conforme veremos a seguir, a combinaçáo de uma série de fatores contribuiu para uma melhoria da renda entre a populaçáo e, por conseguinte, para a ampliação do consumo entre as camadas populares durante a última década ${ }^{1}$.

A redução da pobreza ao longo da última década envolveu diferentes processos de ordem social e territorial. A pobreza apresenta-se hoje menos concentrada nas áreas rurais, já que em 1992, os estratos rural, urbano e metropolitano concentravam $24,3 \%, 44,5 \%$ e $31,2 \%$ da pobreza brasileira, enquanto em 2009 , estes percentuais alcançavam respectivamente 15,3\%, 48,4\% e 36,4\% (Rocha, 2009). A atual intensidade da pobreza nas metrópoles brasileiras, onde o custo de vida é mais elevado e a produção de necessidades mais exacerbada, encontra-se ilustrada na tabela 1 , a seguir. Vale destacar que a proporção de domicílios com rendimento médio mensal até 2 salários mínimos, ou seja, de até $1 / 2$ salário mínimo per capita, corresponde à definição oficial mais correntemente adotada no Brasil enquanto linha de pobreza (Rocha, 2006; IBGE/PNAD, 2009).

1 Cabe esclarecer que a partir de 2015 o processo de distribuição de renda na sociedade brasileira vem apresentando certas tendências de retrocesso, diante da conformação de uma nova conjuntura política e macroeconômica nacional. O desaquecimento do mercado de trabalho, o retorno da inflação, a redução da oferta de crédito, o aumento das taxas de juros e a consequente retração do consumo conformam um novo quadro que impacta, certamente, as dinâmicas analisadas neste artigo. Os processos sociais e as formas geográficas aqui apresentadas, portanto, dizem respeito à reconfiguração da pobreza metropolitana que se deu até o período anterior à "crise" pela qual passa o Brasil a partir do ano de 2015 . 
TABela I | Brasil. Domicílios particulares com rendimento médio mensal até 2 salários mínimos nas Regióes Metropolitanas - 2013

\begin{tabular}{|l|c|}
\hline \multicolumn{1}{|c|}{ REGiáo METROPOLITANA } & \% DE DOMicílios \\
\hline Belém & 36,8 \\
\hline Fortaleza & 39,7 \\
\hline Recife & 41,0 \\
\hline Salvador & 36,7 \\
\hline Belo Horizonte & 22,3 \\
\hline Rio de Janeiro & 25,8 \\
\hline São Paulo & 18,5 \\
\hline Curitiba & 19,2 \\
\hline Porto Alegre & 21,6 \\
\hline
\end{tabular}

FONTE ELABORAÇÃO PRÓPRIA A PARTIR DA PNAD 2013 (IBGE)

A população empobrecida residente nas metrópoles brasileiras encontra-se, não obstante, cada vez mais inserida nas práticas de um consumo moderno e dos nexos financeiros, dinâmicas intrínsecas ao período atual. A metropolização, a redução da pobreza e a ampliaçáo do consumo entre as camadas de baixa renda apresentam-se, assim, como fenômenos inter-relacionados.

A redução da pobreza e a expansão recente do consumo entre os estratos inferiores de renda no Brasil explicam-se por um conjunto de fatores de ordens diversas ocorridos na última década (Torres, Bichir \& Carpim 2006; Montenegro, 2014). Dentre estes, destacam-se o papel das políticas públicas federais de transferência de renda (principalmente o Bolsa Família e o Brasil sem Miséria), os reajustes do valor do salário mínimo -com o consequente aumento da renda do trabalho-, a redução do tamanho médio das famílias no país, a crescente participação feminina no mercado de trabalho, uma menor variação na estrutura de preços e a maior oferta de crédito.

Ao longo dos anos 2000, houve efetivamente uma forte expansão da presença de bens de consumo duráveis nos domicílios do país. Eletrodomésticos como fogáo, geladeira e televisão praticamente se universalizaram nas residências brasileiras: em 2013, 97,2\% dos lares possuíam geladeiras, 98,7\% fogão e 97,1 \% televisão (IBGE/ PNAD, 2013). A evolução da presença de certos bens duráveis nos domicílios brasileiros entre 2001 e 2013 pode ser entrevista na tabela 2.

É interessante notar, a partir da tabela 2, como artefatos modernos como computadores e aparelhos de DVD, até recentemente exclusivos das camadas de maior renda, também se banalizaram nos últimos anos. $\mathrm{O}$ telefone celular constitui um dos itens emblemáticos desta expansão do consumo na última década: enquanto em 1999 havia 15 milhóes de linhas ativas no país, em 2015 já eram 270 milhóes, das quais 196 milhóes funcionavam no sistema de pagamento pré-pago, adotado sobretudo pela população de baixa renda. O serviço de televisão por assinatura, um dos novos consumos de entretenimento representativos da globalizaçáo, também 
apresenta forte expansão no período recente. Se em 2000 havia cerca de 3,5 milhóes de assinaturas no país, em 2015 já eram mais de 19 milhóes (Agência Nacional de Telecomunicaçóes [ANATEL], 2015).

TABEla 2 | Brasil. Distribuição percentual dos domicílios particulares permanentes, segundo a presença de bens duráveis (\%) -2001, 2007, 2013

\begin{tabular}{|l|c|c|c|}
\hline \multicolumn{1}{|c|}{ BENS DURÁVEIS } & $\mathbf{2 0 0 I}$ & $\mathbf{2 0 0 7}$ & $\mathbf{2 0 I} \mathbf{3}$ \\
\hline Fogão & 97,6 & 98,2 & 98,7 \\
\hline Geladeira & 85,1 & 91,4 & 97,2 \\
\hline Freezer & 18,8 & 16,2 & 17,0 \\
\hline Máquina de lavar roupa & 33,7 & 40,0 & 57,4 \\
\hline Rádio & 88,0 & 88,4 & 75,7 \\
\hline Televisão & 89,0 & 94,8 & 97,1 \\
\hline DVD & - & - & 72,0 \\
\hline Computador & 12,6 & 27,0 & 48,8 \\
\hline Acesso à Internet & 8,6 & 20,4 & - \\
\hline Automóvel & - & - & 43,6 \\
\hline
\end{tabular}

FONTE PNAD (IBGE), 200I/2007/20I 3

O lazer, a saúde e a beleza se destacam igualmente entre os segmentos que assumiram recentemente maior importância no consumo dos diferentes estratos da população. $\mathrm{O}$ consumo de produtos de higiene pessoal, perfumaria e cosméticos apresentou um crescimento de mais de $10 \%$ apenas entre 2010 e 2011 no país. Além de registrar o maior crescimento de consumo de produtos destes segmentos nos últimos anos, o Brasil concentra o terceiro maior mercado consumidor do ramo no mundo (Miguel, 2012).

Uma série de indicadores revela mais precisamente como a expansão recente do consumo se estende às camadas mais pobres da população brasileira. Em 2013, mais de $10 \%$ dos domicílios com insegurança alimentar grave -situação que pode chegar à fome- tinham microcomputador com acesso à internet; em 13,8\%, havia micros sem web; em 88,4\%, televisão; em 21,8\%, máquina de lavar roupa; em 85,8\% geladeira; e em 93,5\%, fogão. Esses porcentuais cresceram em comparação ao ano de 2009 , quando eram respectivamente $3,3 \%, 6 \%, 86 \%, 11,9 \%, 75,5 \%$ e $93,6 \%$. Esta expansão também se verificou em relação à posse de bens como motocicleta, cuja presença aumentou de $7,1 \%$ para $12,95 \%$, e do automóvel, cuja posse passou de $5,8 \%$ para $8,9 \%$ no período. O acesso facilitado ao consumo contrasta, no entanto, com o agravamento das condições sociais e de alimentação nestes domicílios (IBGE/ PNAD, 2013). 


\section{Capilarização do crédito e financeirização do território}

Um fator catalizador do consumo nas cidades reside na própria financeirização da vida cotidiana, resultante, dentre outros, de uma maior acessibilidade ao crédito (Contel, 2006). O aumento da oferta de crédito, ou ainda, o processo mais amplo de creditização do território e da sociedade (Santos e Silveira, 2001) constitui, com efeito, um elemento determinante da expansão recente do consumo entre as camadas de baixa renda no Brasil. Esse processo se dá com maior intensidade nas metrópoles, onde o acesso aos canais materiais e imateriais do sistema financeiro é mais amplo.

A expansão do mercado de crédito foi intensificada na década de 1990 com a difusão das novas tecnologias da informação, a implementação de políticas sob a égide neoliberal e a estabilização da moeda, configurando, por fim, uma base normativa estável para a atuação das instituições de crédito no país (Dias, 1992; Arroyo, 2006). A reestruturação do sistema financeiro nacional, pautada pela privatização e desregulamentação, resultou, dentre outros, na flexibilização normativa concernente às instituiçóes de crédito e, por conseguinte, na multiplicação e diversificação de agentes credores no país, dentre os quais se destacam os bancos privados e as agências financeiras de crédito pessoal.

Nos anos 2000, a renovação da base técnica e organizacional que rege o funcionamento da atividade bancária e financeira fortaleceu ainda mais o papel das finanças enquanto variável determinante no território brasileiro. Segundo Contel (2006), a conformação de uma nova topologia bancária, alcançada pela maior presença dos fixos geográficos bancários -como agências, caixas eletrônicos, postos de atendimentos e correspondentes bancários- e a difusão de novos canais eletrônicos garantiram não só a maior oferta de serviços bancários, mas uma ampla expansão da capilaridade da concessão de crédito, resultando em uma "hipercapilaridade das finanças" no território brasileiro.

A expansão da oferta de crédito constitui, com efeito, o grande catalisador da ampliação do consumo. A "imediaticidade" garantida pelo crédito potencializa ainda mais seu poder de sedução, visto que sua facilidade proporciona ao consumidor acesso imediato a um bem cuja renda não permitiria aceder. Renova-se, aí, o fenômeno da "coerção da compra", característico da "sociedade do consumo" descrita por Baudrillard nos anos 1960. Entre a populaçáo brasileira, o impulso da compra atende, em grande medida, a uma demanda legítima, mas reprimida durante anos. Se o padrão de renda aumenta, há, concomitantemente, uma tendência muito forte de resposta a essa demanda. A expansão do mercado creditício no país é evidenciada, entre outros, pelo aumento do volume das operaçóes de crédito do Sistema Financeiro Nacional (sFN), que atingiram R \$ 2,715 trilhóes em 2013, valor treze vezes superior ao registrado no ano de 1995, quando chegaram a R \$202,6 bilhóes (Banco Central do Brasil [всв], 2014).

No Brasil, outro fator explicativo da financeirização -sobretudo desta que atinge a população de menor renda- foi o surgimento de novos produtos financeiros, especificamente elaborados para cada estrato social. Diversas modalidades de crédito voltadas à pessoa jurídica e à pessoa física foram aperfeiçoadas e ampliadas nos 
últimos anos. Dentre aquelas ofertadas à pessoa física por instituiçôes bancárias, destacam-se o crédito consignado em folha de pagamento, os cartóes de crédito, o crédito pessoal, o crédito imobiliário e o crédito rural. Desde meados da década de 1990, a expansão do crédito tem se sustentado sobretudo no crescimento destas operaçóes contratadas por pessoas físicas: enquanto em 1995 movimentaram R \$12,9 bilhôes, em 2013 passaram a R \$1,251 trilhão (всв, 2014).

Nos últimos anos, o processo de financeirização e a creditização têm deixado, contudo, de limitar-se à ação dos capitais bancários tradicionais (Dias, 2009; De Mattos, 2014), haja vista a crescente oferta de crédito por parte de instituiçóes financeiras não bancárias, como agências financeiras de crédito pessoal e grandes redes de varejo. $\mathrm{O}$ protagonismo no processo de financeirização deixou de se limitar, assim, à ação dos bancos e instituiçôes especificamente financeiras, passando a ser exercido também por grandes cadeias de comércio varejista (de eletrodomésticos, roupas e materiais de construção, entre outros). Essas empresas obtêm, muitas vezes, maior lucratividade com a venda de produtos financeiros, como o crédito ao consumidor, do que com a venda das mercadorias que fabricam ou comercializam. Os juros incorporados às prestaçóes excedem significativamente, ademais, o valor real dos artigos vendidos. Destarte, operaçôes puramente financeiras dos grandes grupos adquirem maior importância no conjunto de suas atividades, resultando em uma crescente migração dos capitais da esfera do investimento para a esfera da especulação (Chesnais, 1998).

Diversificam-se, assim, as estratégias de creditização e financeirização da população de baixa renda por parte das maiores empresas para garantir a inserçáo desse estrato da populaçáo em seu mercado consumidor. Desenvolve-se, nessa direção, uma nova e complexa organização do circuito superior da economia urbana (Santos, 1975; Silveira, 2011), composto por associaçôes entre instituiçôes financeiras bancárias, suas respectivas instituiçóes financeiras de crédito pessoal e grandes redes de varejo e de serviços, constituídas, em grande medida, para abarcar os pobres no mercado de consumo.

Verifica-se, com efeito, que as principais instituiçōes financeiras de crédito pessoal atuantes nas cidades brasileiras, que oferecem um crédito fácil e "desburocratizado", pertencem a grandes bancos: a Finasa pertence ao Bradesco, a Losango ao HSBC, a Fininvest ao Itaú/Unibanco, a BV Financeira ao Banco Votorantim, a Pan ao Banco Panamericano, a Citifinacial ao Citigroup, a Ibi ao cofra Holding e Elopar (em associação aos Banco do Brasil e Bradesco). Esses grupos associam-se, por sua vez, a grandes cadeias comerciais de varejo de eletrodomésticos, vestuário e materiais de construção -como Lojas Pernambucanas, Ponto Frio, Leroy Merlin, Marisa- passando mais recentemente a se associar também a empresas aéreas e de serviço de TV por assinatura, correspondentes a novas aspiraçóes de consumo entre as camadas de menor poder aquisitivo.

Protagonistas deste processo de creditização da população de baixa renda, os grandes conglomerados empresariais e financeiros parecem ter reconhecido a "necessidade de desburocratizar o crédito", posto que a rigidez e quantidade dos requisitos para o acesso a cartóes e empréstimos -que hoje muitas vezes se limitam 
à apresentação de $\mathrm{RG}, \mathrm{CPF}^{2}$ e talóes de cheques- se reduzem à medida que aumenta o custo do dinheiro (Lopes dos Santos, 2007), resultando, por fim, na onipresença de um crédito rápido, formal e livre de exigências (Silveira, 2009).

Dentre os diferentes tipos de empréstimos oferecidos, o crédito pessoal tornouse uma das formas mais desburocratizadas de acesso ao dinheiro nos últimos anos. Enquanto em 2000, o volume de concessão de crédito pessoal foi da ordem de $\mathrm{R} \$ 16,3$ bilhóes, em 2011 já atingia $\mathrm{R} \$ 319,6$ bilhóes (всв, 2012). Esse incremento sustentou-se não apenas em políticas de redução das taxas de juros, mas igualmente na nova geografia bancária instalada no território brasileiro, referida acima. Uma nova topologia, menos dependente das agências e mais estruturada em sistemas de objetos próximos aos circuitos comerciais e produtivos, multiplica a quantidade de seus usuários, aumentando, ao mesmo passo, os volumes e as velocidades da circulação de capitais no território (Contel, 2006).

Ofertados continuamente por bancos, instituiçôes financeiras de crédito pessoal e redes varejistas, os cartôes constituem uma modalidade de crédito com amplo poder de difusão entre as diferentes classes de renda. Ao antecipar os recursos financeiros que permitem a realização da compra, o cartão de crédito se torna um artefato que potencializa o fenômeno do consumo. Seu uso implica, no entanto, o pagamento de juros e serviços prestados pela administradora dos sistemas técnicos que envolvem sua utilização. O aumento da quantidade de cartôes (crédito, débito e de lojas) no país ao longo dos últimos anos compreende um indicador expressivo de sua difusão: entre 2000 e 2012, o número de cartôes cresceu mais de 590\%, passando de 119 milhôes para 704 milhões de unidades (Associação Brasileira das Empresas de Cartôes de Crédito e Serviços [ABECs], 2012).

Os cartôes de redes e lojas, que já totalizam mais de 225 milhôes de unidades no país (ABECS, 2012), se destacam entre os novos meios de financeirização da camada de baixa renda por parte das grandes redes varejistas. Conhecidos como "private label', envolvem a fidelização de clientes através da oferta de crédito, vales, bônus, preços promocionais e prazos estendidos para pagamentos de parcelas sem juros. Os chamados "cartôes híbridos", que podem ser utilizados não só em lojas, mas em qualquer estabelecimento, também se destacam entre os novos instrumentos ofertados. A atual aliança entre bancos, financeiras, redes varejistas e administradoras encontra-se, assim, simbolizada pelo artefato do cartão (Sciré, 2011). Esta busca do mercado por se estender àqueles com rendimentos mais baixos, especialmente através da indústria de cartóes de crédito e do endividamento, é, como coloca Harvey (2011), justamente uma das características centrais do capitalismo que se intensifica nos dias de hoje. Em posse de crédito, as famílias de baixo poder aquisitivo puderam, efetivamente, ir "às compras".

2 O Registro Geral (RG) e o Cadastro de Pessoa Física (CPF) constituem documentos oficiais no território brasileiro. 


\section{Da financeirizaçáo ao endividamento e à inadimplência}

Se, por um lado, a profusão das formas de crédito, combinada aos demais elementos referidos, permitiu o aumento do consumo entre as diferentes classes de renda, por outro lado, tem implicado igualmente o avanço do endividamento, da inadimplência e da insolvência entre a população brasileira.

$\mathrm{O}$ acesso facilitado ao crédito se confronta, necessariamente, com a dificuldade em arcar com os custos que permitem seu desfrute, resultando no endividamento sistemático de muitas famílias. A desburocratização das exigências de acesso a empréstimos é, em grande medida, compensada pelo aumento do custo do dinheiro, visto que os valores das taxas de juros cobradas em operaçóes de concessão de crédito pessoal por instituiçóes financeiras e redes de varejo podem assumir valores bastante elevados. As taxas de juros cobradas, por exemplo, pela financeira Crefisa são da ordem de $19,71 \%$ ao mês e $766,01 \%$ ao ano; pela financeira das Lojas Pernambucanas chegam a $13,23 \%$ ao mês e $343,92 \%$ ao ano; e pela financeira Losango alcançam 9,55\% ao mês e 198,89\% ao ano (вСв, 2015). Como afirma Sciré (2011, p. 76), "a financeirização e seus artefatos possibilitaram a aquisição de bens sob uma lógica que dissocia o acesso ao consumo dos rendimentos efetivos do trabalho, gerando outro jogo de relaçóes pautado pelo trinômio crédito-consumo-endividamento".

$\mathrm{O}$ poder de sedução, exercido, em um primeiro momento, pela publicidade e pela possibilidade da compra em parcelas diluídas a prazo, se materializa, em um segundo momento, no enfrentamento dos juros e na reorganização do orçamento doméstico para lidar com o pagamento de diferentes dívidas contraídas simultaneamente. De acordo com o Instituto de Pesquisa Econômica Aplicada ipea (2013), o consumidor brasileiro de baixa renda tende a dar preferência, no ato da compra, ao maior número de prestaçóes possíveis com o menor valor referencial, desconsiderando, muitas vezes, as taxas de juros embutidas nas parcelas. Destarte, se por um lado a expansão do acesso ao crédito tem garantido a crescente aquisição de bens e serviços entre a população de baixa renda -transformando seu cotidiano através da "antecipação do proveito das coisas"- por outro lado, o vencimento das prestaçôes logo se confronta com a realidade socioeconômica destas famílias. Daí o aumento do endividamento e da inadimplência entre a população de baixa renda: dentre as famílias com renda até 10 salários mínimos no país, verifica-se, por exemplo, que 63,0\% encontravam-se endividadas e 26,3\% inadimplentes no início de 2016 (Federação do Comércio de Bens, Serviços e Turismo de São Paulo [Fecomércio sP], 2016).

$\mathrm{O}$ avanço do endividamento na sociedade brasileira coincide, assim, com a recente expansão da oferta de crédito no país. O percentual de famílias endividadas passou de uma média anual de 59,1\% do total em 2010 para 63,9\% em 2015, ano em que o cartão de crédito foi a modalidade mais apontada pelas famílias endividadas entre seus principais tipos de dívida (77,4\% do total) (Fecomércio sp, 2015).

O cartão de crédito se destaca, efetivamente, como um dos principais artefatos que permitem a movimentação da engrenagem entre a obtenção do crédito, o consumo e o endividamento. Entre a população de baixa renda, no entanto, o cartão acaba servindo, muitas vezes, a uma rolagem constante da dívida, provocando, 
consequentemente, o aprofundamento do endividamento e do empobrecimento. O comprometimento médio da renda das famílias endividadas foi de 30,2\% da renda mensal em 2013, sendo que 21,8\% destas famílias apresentavam mais da metade de sua renda comprometida com o pagamento de dívidas (Fecomércio sp, 2013, 2016).

Os indicadores elencados acima nos revelam a dimensão do círculo vicioso que se estabelece entre consumo, endividamento e empobrecimento (Silveira, 2009). A possiblidade de obter dinheiro adiantado acaba servindo, porém, não apenas ao consumo, mas também ao pagamento de dívidas atrasadas oriundas de empréstimos anteriores e à obtenção de dinheiro líquido para obtenção de novo crédito no mercado.

\section{Oligopolizaçáo do território e reconfiguraçáo da periferia}

As atuais estratégias dos conglomerados para ampliar seu mercado consumidor às camadas de menor renda náo se restringem, contudo, à expansão da oferta de crédito. Para além da creditização, as maiores empresas têm adotado também a diversificação de suas topologias nas grandes cidades brasileiras. Na maior metrópole do país, há, certamente, uma enorme heterogeneidade de situaçóes de pobreza. Neste ponto, contudo, buscamos analisar uma gama de situaçóes geográficas e informaçôes primárias obtidas em trabalhos de campo na periferia de São Paulo, mais especificamente nos bairros de Campo Limpo e Jardim São Luiz, na zona sul, e Itaquera, na zona leste, e no Município de Taboão da Serra, na porção oeste da metrópole (figura 1) ${ }^{3}$. Buscamos identificar aí situaçôes geográficas reveladoras de como os nexos financeiros se capilarizam pela periferia por meio da abordagem junto a grandes redes varejistas recém-instaladas nestes bairros, a pequenos estabelecimentos do circuito inferior e à população aí residente. A valorização diferencial do tecido urbano, a concorrência pelo mercado popular entre redes recém-instaladas e pequenos negócios, assim como a transformação das práticas de consumo e deslocamentos pautaram a escolha de situaçóes analisadas.

Embora a população pobre se faça presente por toda parte, habitando zonas deterioradas, cortiços e enclaves de áreas valorizadas, o lugar onde se concentra e que constitui a expressão mais clara do seu modo de vida é a chamada "periferia" (Durham, 2004). A periferização da pobreza retrata, com efeito, a conformação de espaços de pobreza onde seguem se acumulando uma série de desvantagens (Aguilar \& López Guerrero, 2016). Em metrópoles como São Paulo, as periferias caracterizam-se, tradicionalmente, como localizaçóes marcadas pela pobreza e pela precariedade, uma vez que agregam áreas desvalorizadas onde reside mormente uma população de baixa renda (figura 2) e predominam infraestruturas precárias e equipamentos de serviços deficientes (Bonduki \& Rolnik, 1979). 
Figura I | Áreas de Estudo na Região Metropolitana de São Paulo

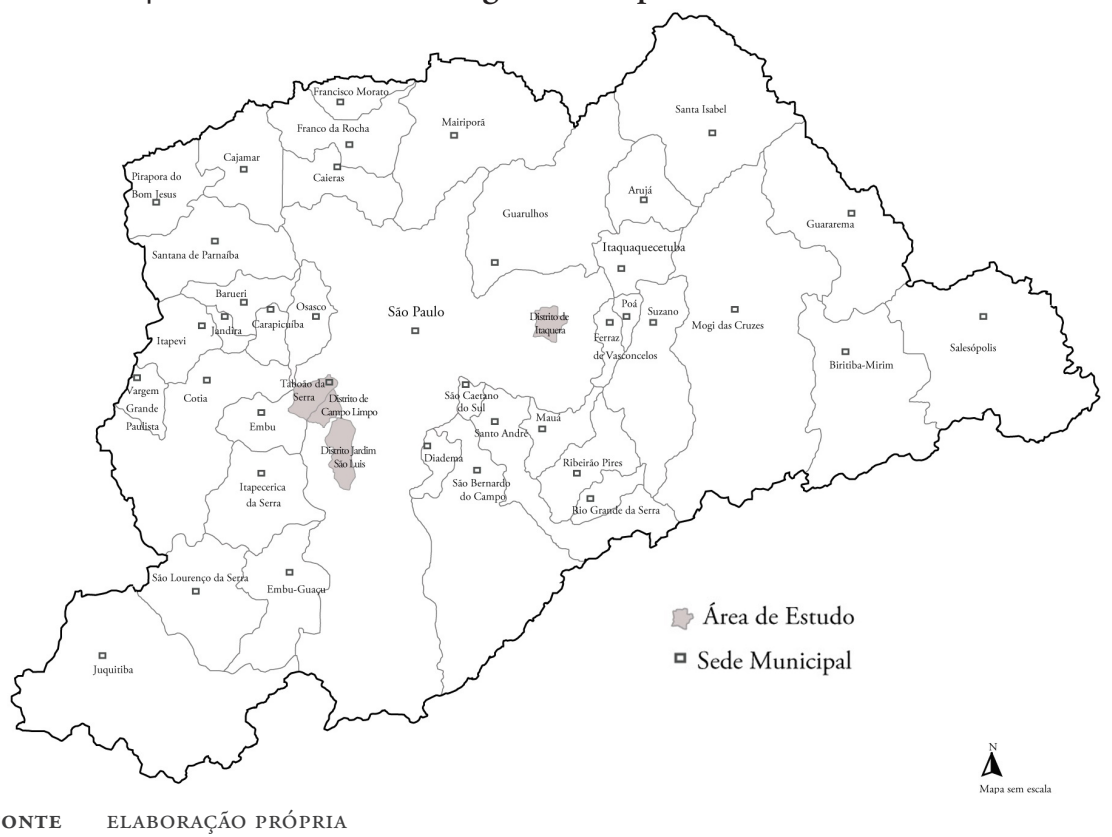

Nos últimos anos, contudo, agências financeiras e grandes redes de comércio e serviços do circuito superior vêm buscando inserir-se em locais até então considerados relativamente desinteressantes pelas maiores empresas em São Paulo (Silveira, 2009). Daí a crescente presença de agências bancárias, instituições financeiras de crédito pessoal, shopping centers, hipermercados, supermercados e filiais de grandes redes de varejo e serviços não apenas em centralidades populares, mas também em bairros periféricos considerados até então mercados "pouco dinâmicos".

A recente instalação destes estabelecimentos nas áreas analisadas ilustra este processo, visto que praticamente a totalidade das grandes empresas onde foram realizadas entrevistas ${ }^{4}$ se encontra em suas localizaçóes há menos de dez anos. Projetos de expansão a novas áreas e o perfil da clientela se destacam como as principais razóes apresentadas para a escolha dos pontos, considerados adequados pela maioria justamente em função do tamanho do mercado reunido na periferia e do volume de consumo por ele realizado. A divisão territorial do trabalho de grandes corporaçóes passa a estender-se, assim, a novas porçôes do território urbano, conformando um movimento que conta, muitas vezes, com o auxílio do próprio Estado. Estes agentes do circuito superior buscam instalar-se, sobretudo, em subcentralidades de bairros periféricos como praças, largos, proximidades de terminais e pontos de ônibus e estaçóes de metrô.

4 Dentre as empresas do circuito superior entrevistadas, destacam-se o hipermercado Extra, as redes varejistas de eletrodomésticos e móveis Casas Bahia, Magazine Luiza, Marabraz, Lojas Cem e Ponto Frio, as redes de farmácia Drograsil e Farmais, além de franquias como Cacau Show e Boticário, dentre outras. 
FIgURA 2 Renda Média per capita por Distrito no Município de Sáo Paulo - 2010

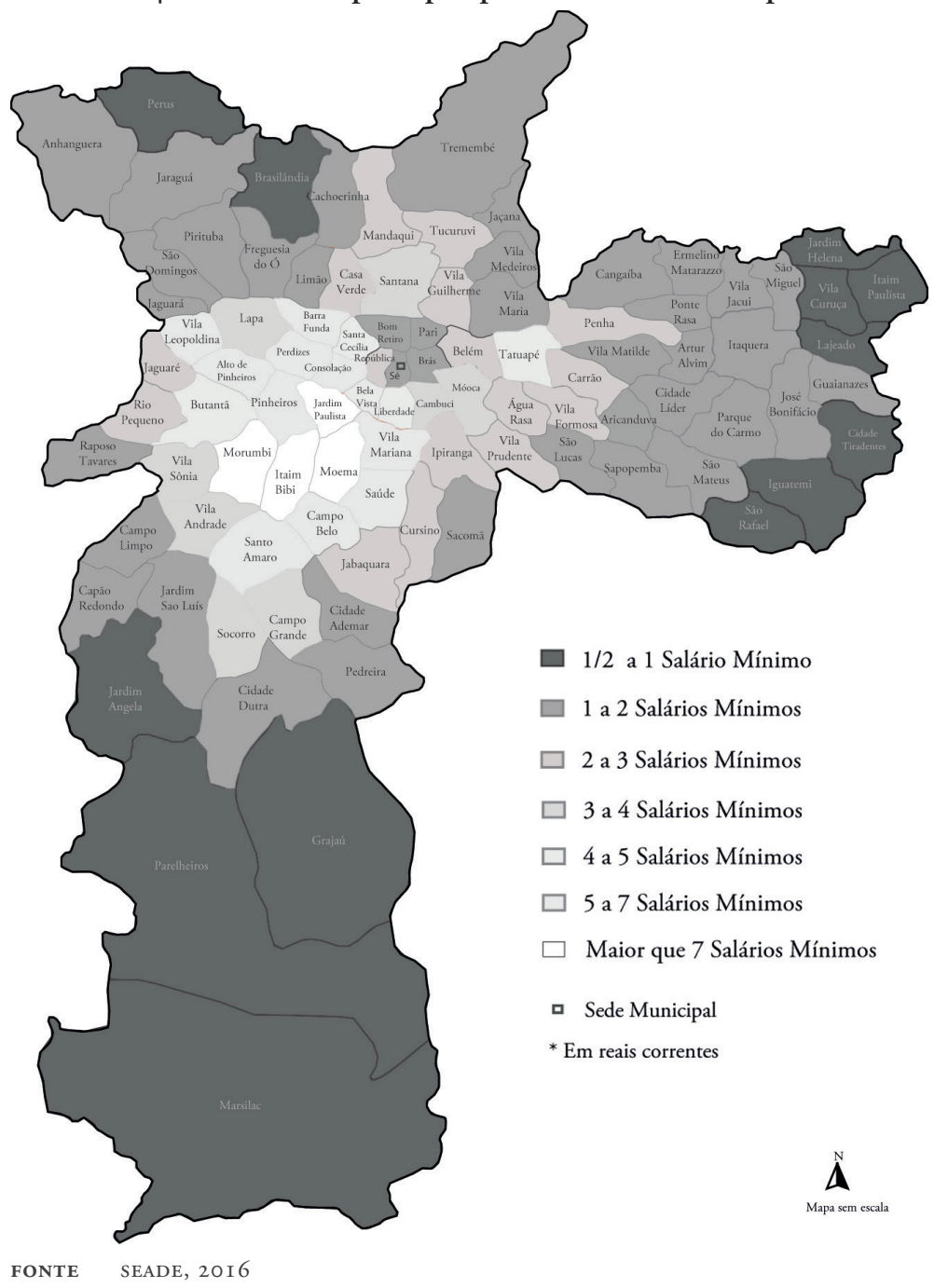

A recente proliferação das agências financeiras de crédito pessoal em São Paulo explicita, por sua vez, a "vontade colonizadora" das redes bancárias, e financeiras de que falava Labasse (1974), visto que as infraestruturas financeiras são impelidas para o maior número de lugares de onde é possível drenar recursos, através da venda de produtos financeiros e da concessão de empréstimos. Ao tamanho do mercado reunido na periferia, agora provido de crédito, acresce-se a disponibilidade de grandes superfícies e menores custos de aluguel em comparação às áreas centrais. A localização das principais agências financeiras de crédito pessoal na Região Metropolitana de São Paulo, ilustrada nas figuras 3, 4, 5 e 6, revela sua difusão territorial para além do centro antigo da cidade e a capilaridade alcançada por estas redes. 
FIgura 3 | Estabelecimentos da Crefisa na Região Metropolitana de São Paulo - 2015

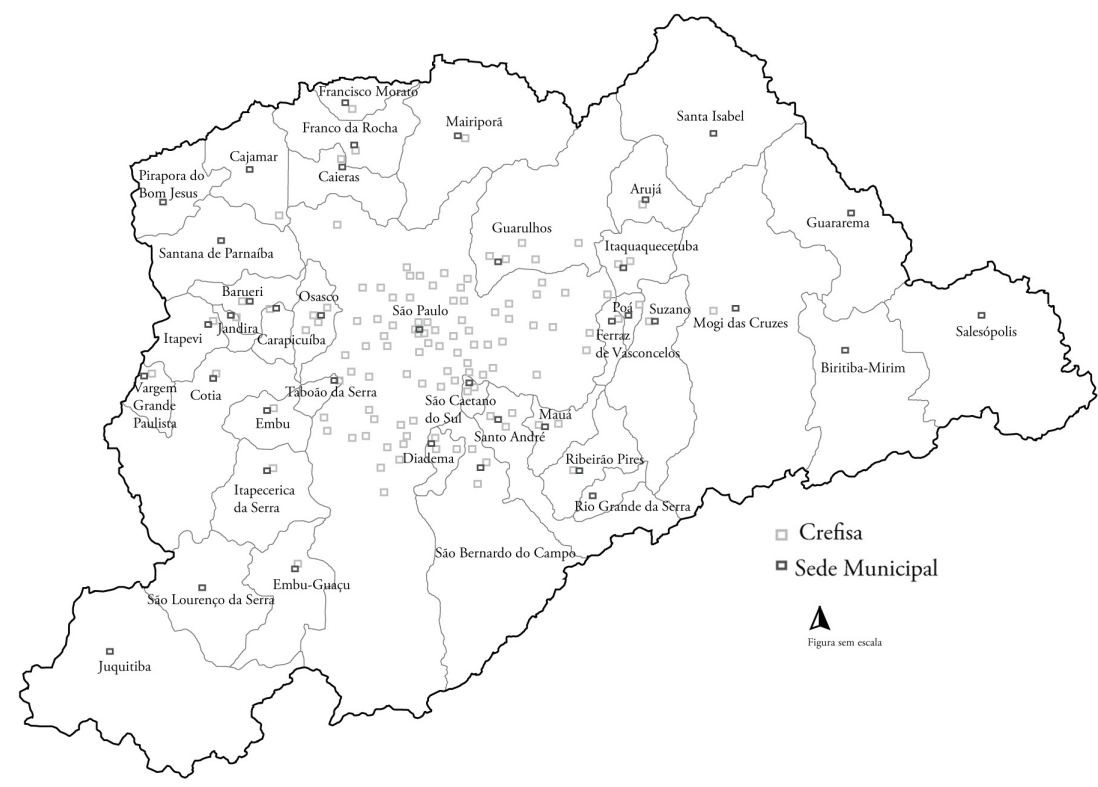

FONTE CREFISA, 2015

Figura 4 | Estabelecimentos da Finasa na Região Metropolitana de São Paulo 2015

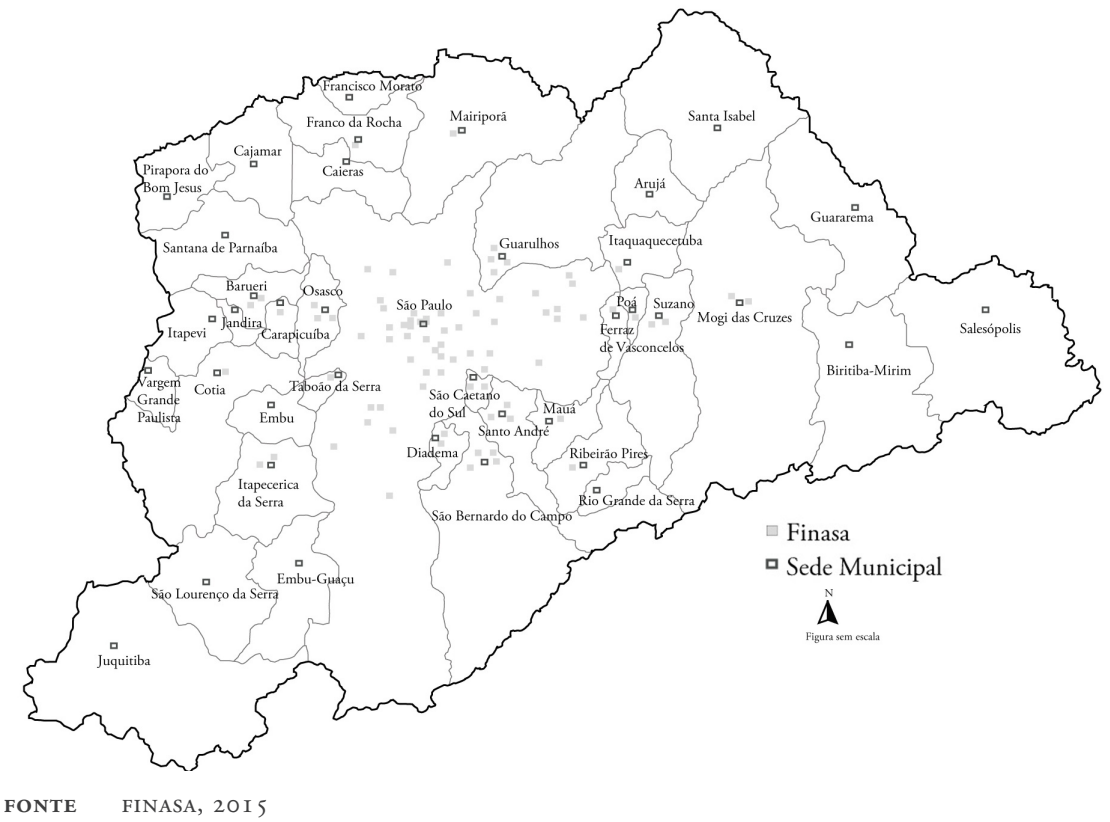


Figura 5 | Estabelecimentos da Fininvest na Regiáo Metropolitana de Sáo Paulo - 2015

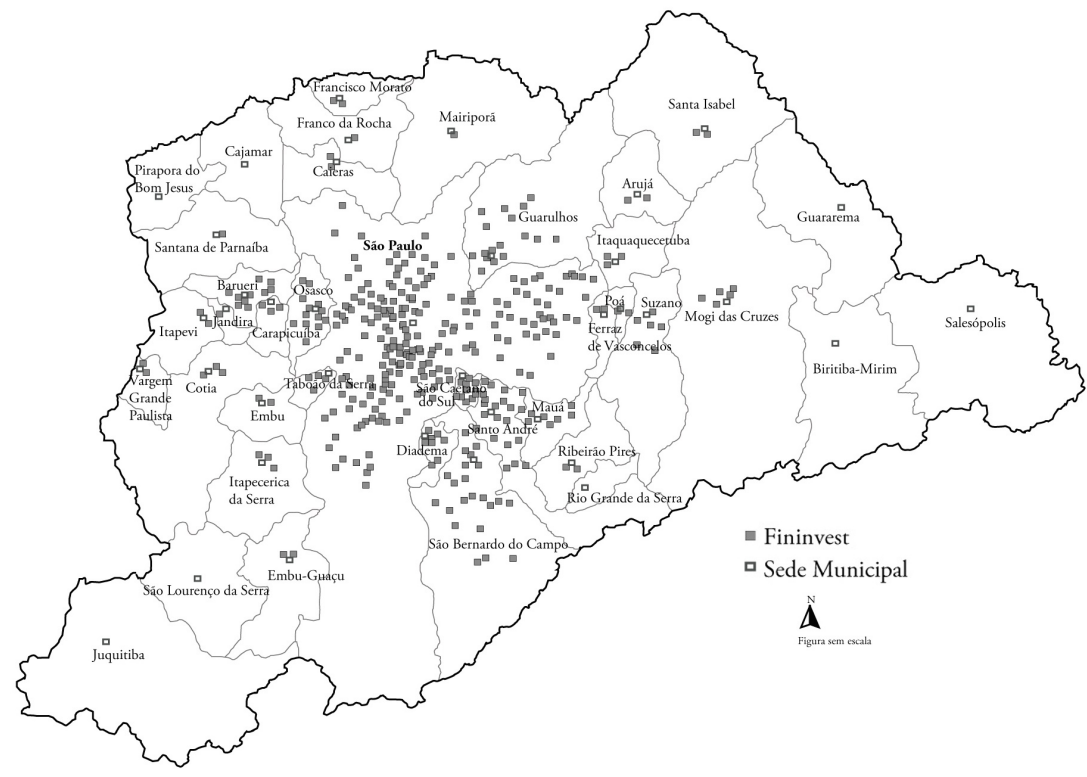

FONTE FININVEST, 20 I 5

FIgura 6 | Estabelecimentos do Ibi na Regiáo Metropolitana de São Paulo 2015

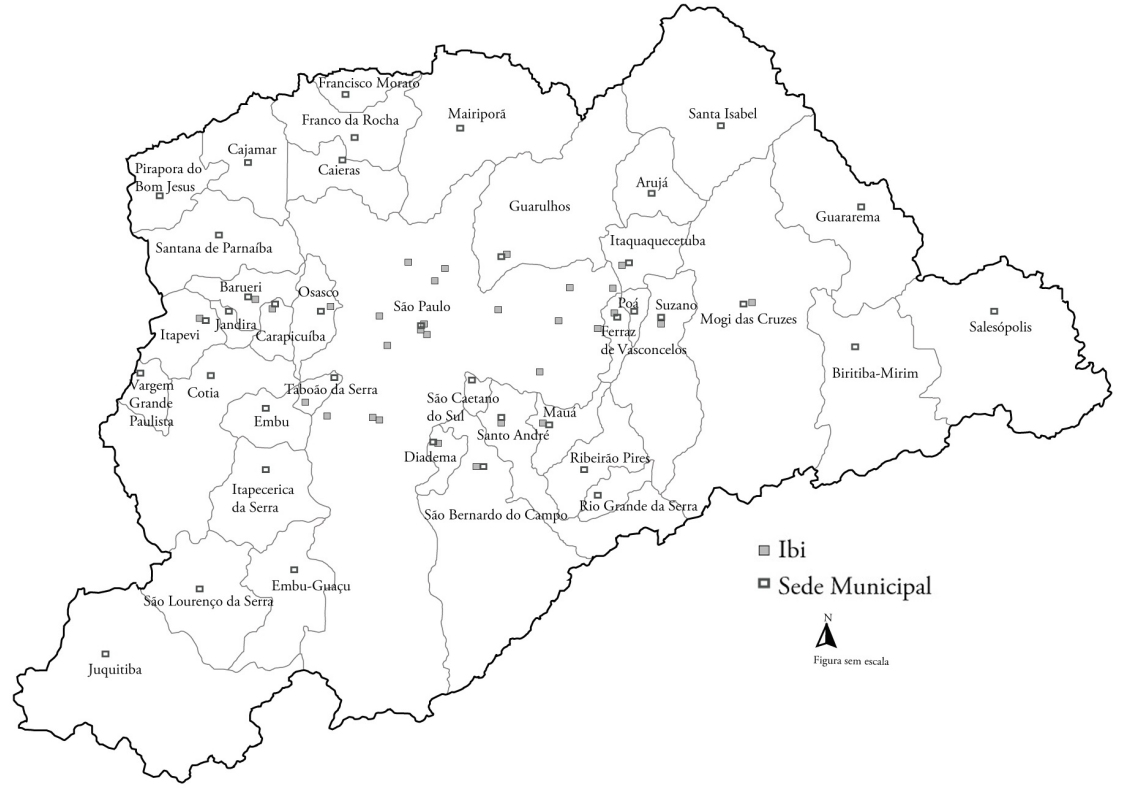

FONTE IBI, 20 IS 
Dentre as agências financeiras de crédito ilustradas, Finasa e Crefisa se destacam como aquelas com o maior número de lojas em São Paulo, fazendo-se presentes não só em seu centro expandido, mas nas periferias das zonas leste e sul, nas proximidades de Santo André, São Bernardo do Campo, São Caetano (a "região do ABC") e em municípios como Taboão da Serra, Osasco, Itapecerica da Serra e Carapicuíba. A Crefisa possui atualmente 63 lojas apenas no Município de São Paulo e mais 36 nos demais municípios da Região Metropolitana. Já a rede Finasa possui 47 lojas no Município de São Paulo, as quais se acrescentam mais 36 nos demais municípios da Região Metropolitana. No espaço intra-urbano, a topologia das financeiras e dos bancos especializados em atender as camadas de baixa renda se materializa não só por meio de lojas próprias, mas através de pontos de venda, quiosques em supermercados, hipermercados, estaçóes do metrô e shopping centers populares.

A difusão dos shopping-centers em São Paulo nos últimos anos também integra as recentes transformaçóes territoriais em sua periferia. A metrópole de São Paulo contabiliza atualmente 55 shopping-centers espalhados por seu tecido urbano (Associação Brasileira de Shopping Centers [ABRASCE], 2015). Embora estejam concentrados nas áreas centrais, os shoppings e lojas de grandes empresas se espraiaram recentemente para bairros mais periféricos da cidade, como Campo Limpo, Jardim São Luiz e Socorro na zona sul, e Itaquera e São Miguel na zona leste, assim como para cidades que margeiam o Município de São Paulo e reúnem grandes periferias pobres, como Taboão da Serra e Itapecerica da Serra, logrando, assim, um alcance de maior escala junto à populaçáo de baixa renda (figura 7).

FIgura 7 | Shoppings Centers na Região Metropolitana de São Paulo - 2014

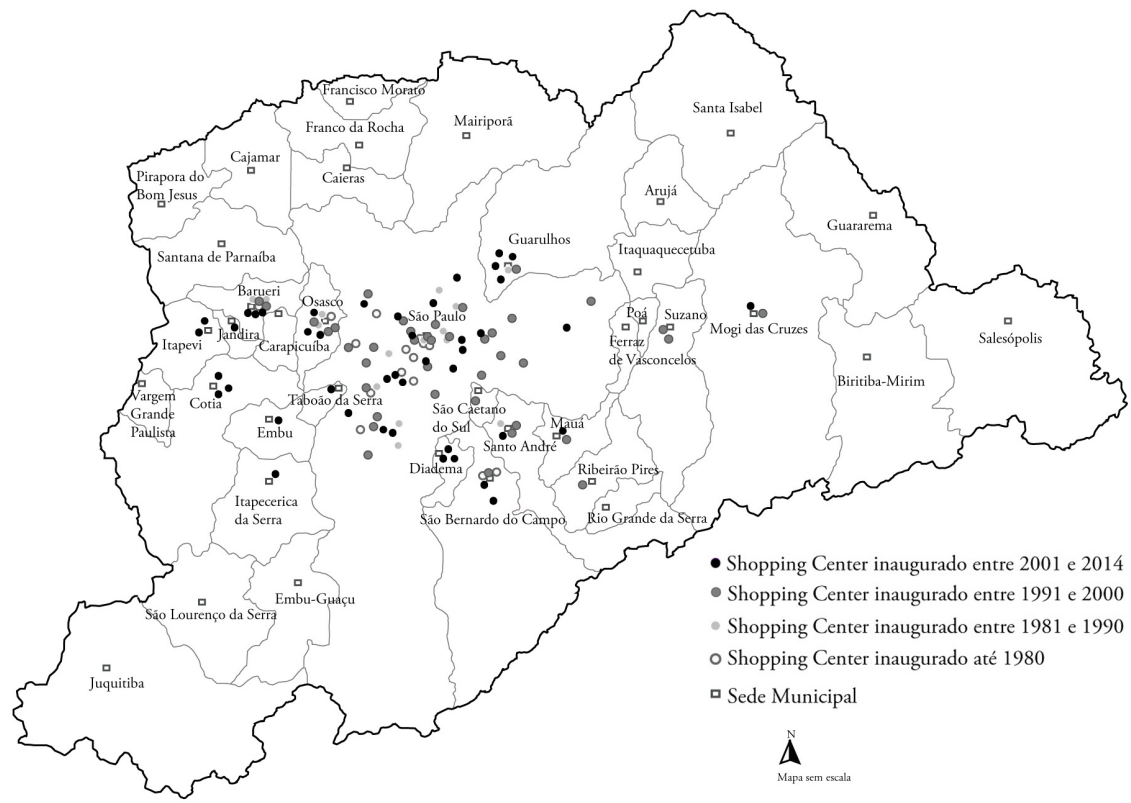

FONTE ABRASCE, 2OI 4 
A difusão das grandes redes varejistas no tecido urbano da metrópole paulistana se dá no mesmo sentido e intensidade. Muitas vezes alojadas dentro de shoppings, as redes de varejo de móveis, eletrodomésticos e vestuário, como Casas Bahia, Ponto Frio e Lojas Marisa, respectivamente, se destacam entre os agentes do circuito superior que têm alcançado maior capilaridade no território nos últimos anos. Apenas a rede Casas Bahia possui atualmente 142 lojas espalhadas pela Região Metropolitana de São Paulo, das quais 84 se encontram no Município de São Paulo (figura 8). A rede Ponto Frio possui, por sua vez, 49 lojas no Município de São Paulo, contabilizando 79 pontos de venda na Região Metropolitana (figura 9). Já a rede popular de confecçóes Marisa possui 103 estabelecimentos na Região Metropolitana como um todo, das quais 54 localizadas no Município de São Paulo (figura 10).

\section{FIgura 8 | Estabelecimentos das Casas Bahia na Regiáo Metropolitana de} São Paulo - 2014

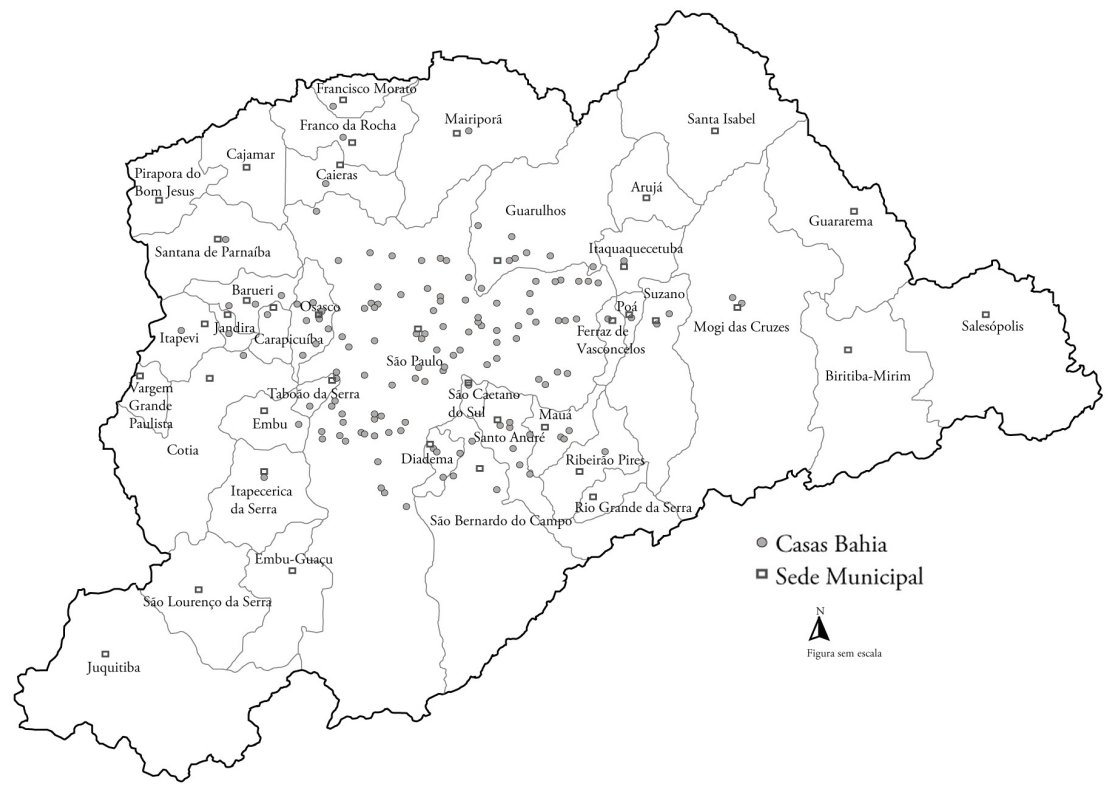

FONTE CASAS BAHIA, 20 I 4

A série de mapas acima revela, para o caso de São Paulo, como as periferias metropolitanas assumem atualmente maior importância na pauta de localização das grandes empresas (Sánchez, 2007). Além de concentrar o comércio popular e pouco capitalizado do circuito inferior da economia, a periferia paulistana passa a reunir também grandes redes varejistas, shopping centers e filiais de redes internacionais de fast food e entretenimento (Koulioumba, 2002). A crescente presença destas empresas tende, ademais, a valorizar áreas periféricas, expulsando, por conseguinte, atividades e moradores menos capitalizados. 
Figura 9 | Estabelecimentos do Ponto Frio na Região Metropolitana de São Paulo - 2014

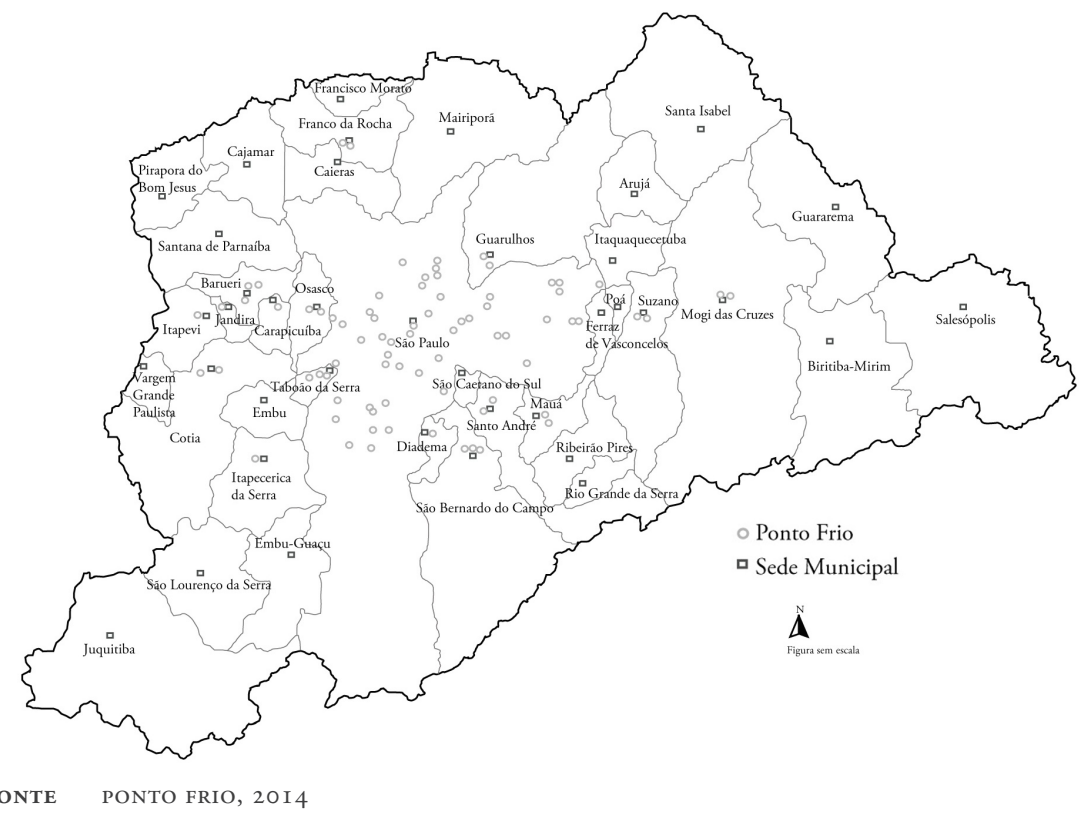

Figura io | Estabelecimentos das Lojas Marisa na Regiáo Metropolitana de São Paulo - 2014

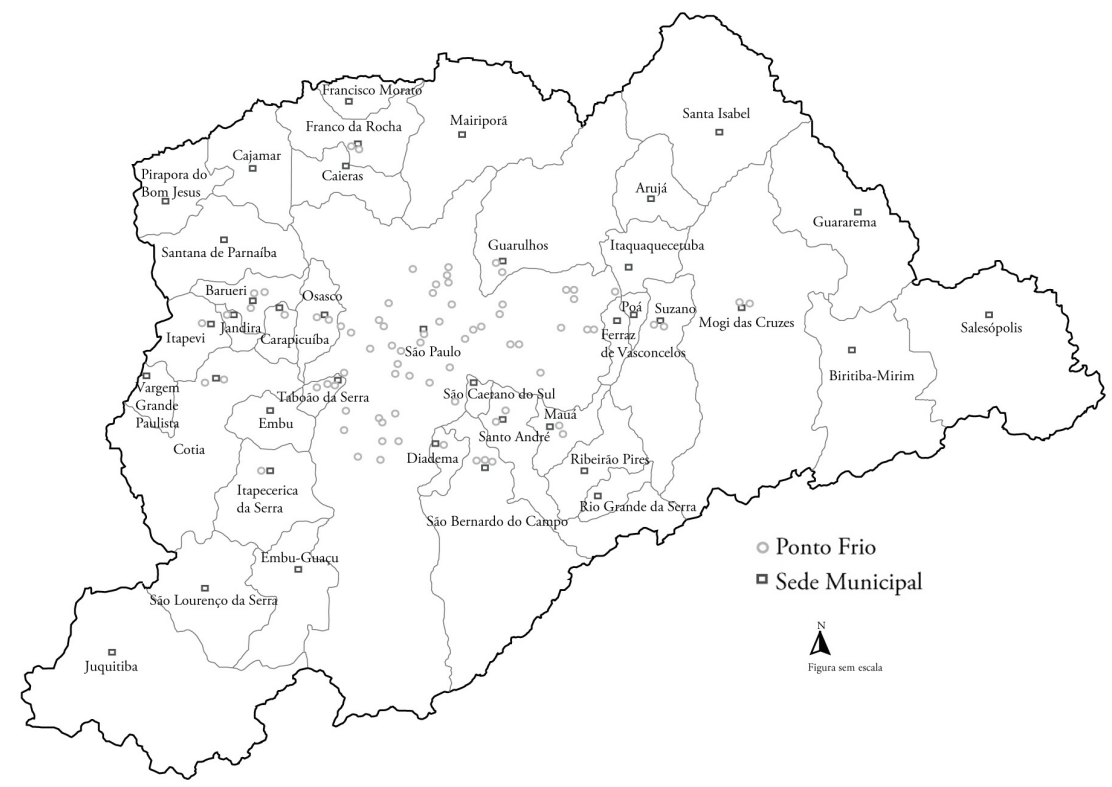

FONTE

MARISA, 2014 
Estes equipamentos acabam por exercer uma grande capacidade de polarização dos fluxos, criando ou reforçando centralidades através das quais se difundem bens e marcas do circuito superior ${ }^{5}$ (Silveira, 2016). Os hipermercados localizados dentro de shopping centers na periferia têm polarizado, de fato, o mercado consumidor aí residente. Dentre os entrevistados, 60\% realizam suas compras domésticas nos hipermercados Extra localizados no interior dos shoppings Itaquera, Campo Limpo e Taboão. Evidencia-se aí a importância da estratégia locacional da rede de supermercados Extra, bandeira popular do Páo de Açúcar, maior grupo supermercadista do país. A reestruturação do setor de supermercados nos últimos anos, com o avanço das fusóes e incorporaçóes, resultou em uma oligopolização do setor sob o controle de três grandes grupos (Pão de Açúcar, Carrefour e Wal Mart). Esses passaram a deter e adquirir não apenas supermercados e hipermercados, mas também redes populares de mercados menores e mercadinhos de bairro. A concentração econômica e financeira, característica do período, induz, deste modo, um movimento de oligopolização do mercado e do próprio tecido urbano.

Eletrodomésticos, roupas e calçados também passam a ser crescentemente adquiridos em lojas localizadas no interior de shoppings situados na periferia. As redes Casas Bahia e Ponto Frio são as mais frequentadas entre os entrevistados para a compra de eletrodomésticos, seja no interior de shoppings ou em lojas de rua. Os eletrodomésticos se destacam, inclusive, como os principais artigos que passaram a integrar as compras deste estrato da população, sendo apontados como a principal transformação recente em seu consumo. Lojas Pernambucanas e Marisa se destacam, por sua vez, como referência para compra de artigos de cama, mesa e banho e vestuário, sobretudo entre o público feminino. A reconfiguração da topologia destas redes vêm provocando, destarte, uma alteração nos deslocamentos para consumo dos moradores da periferia, uma vez que estes passam a frequentar mais os hipermercados e shoppings em suas proximidades e a ir menos ao centro da cidade.

A presença de financeiras e lojas de grandes redes em bairros da periferia da cidade de São Paulo implica, assim, uma série de processos de diversas ordens. A crescente oferta por parte do circuito superior volta-se, agora, a uma demanda anteriormente vinculada sobretudo ao circuito inferior da economia (Silveira, 2009). A consequente diversificação das práticas de consumo da população aí residente em estabelecimentos de diferentes portes redefine o tamanho do mercado de pequenos negócios que passam a enfrentar uma concorrência altamente capitalizada. É interessante destacar, nesta direçáo, que o alcance do mercado de $70 \%$ das lojas das grandes empresas entrevistadas se limita ao próprio bairro, o que implica, certamente, um avanço sobre parcela da clientela anteriormente cativa do circuito inferior.

Pequenos negócios como "vendinhas", açougues e salóes de cabeleireiro, seguem, contudo, captando parte do mercado na periferia, sobretudo para a realizaçáo de compras menores e pontuais. A proximidade e a permanência da possibilidade do

$5 \longdiv { \mathrm { O } \text { acesso a determinadas marcas e a frequência a determinados tipos de estabelecimento adquirem } }$ especial importância simbólica neste processo. Para Sennet (2006), a paixão auto consumptiva não se explicaria mais apenas pelo motor da moda e da publicidade e pela "obsolescência planejada". Hoje, o consumidor se envolveria mais ativamente na paixão do consumo, por meio da exaltaçáo das marcas e da suposta potência embutida nos objetos. 
crédito informal (o chamado "fiado") influenciam as compras diárias miúdas de artigos de primeira necessidade no pequeno comércio de vizinhança, mesmo que, muitas vezes, estes pratiquem preços mais altos do que nos supermercados do bairro e que, inclusive, se abasteçam nestes estabelecimentos. A preferência pela pequena vendinha se fundamenta, ademais, na importância das redes de sociabilidade entre a população de baixa renda nas periferias, ou ainda, da fidelidade característica destas redes de vizinhança. A força da publicidade das grandes redes nos meios de comunicação, o status auferido pelas marcas e a oferta de crédito a prazo constituem, porém, elementos contra os quais os pequenos negócios dificilmente conseguem fazer frente.

Surgem aí novas formas de "capilaridade" assumidas pelas finanças e pelo consumo entre a populaçáo pobre. Redimensiona-se, por conseguinte, o tamanho dos mercados dos estabelecimentos de diferentes portes localizados não só nas periferias, mas na cidade como um todo. Redefine-se, ao mesmo passo, a direçáo de um fluxo já escasso de capital que agora passa a ascender em maior volume do circuito inferior, ou seja, da populaçáo pobre, rumo ao circuito superior da economia. A banalização do acesso aos cartôes entre as diferentes classes de renda, referida acima, se reflete na posse generalizada deste artefato entre os residentes entrevistados na periferia paulistana, assim como em sua ampla aceitação como forma de pagamento nos estabelecimentos do circuito superior e inferior aí localizados. O fato de $85 \%$ dos pequenos negócios analisados aceitarem cartóes de débito e crédito como forma de pagamento configura um indicador bastante revelador do avanço da financeirização da população de baixa renda, que passou a adotar o cartáo como meio de pagamento nos últimos anos.

Para além do parcelamento de compras, consolidam-se hoje novas práticas relativas à gestão financeira e à própria sociabilidade decorrentes da creditização. Dado o baixo nível de renda, as despesas correntes ultrapassam frequentemente a renda mensal dos entrevistados na periferia paulistana. As principais estratégias adotadas nesta situaçáo consistem na utilização do cartão de crédito, na busca por empréstimos, no parcelamento de dívidas, no corte de gastos e no dispêndio da poupança, quando esta existe.

A formação da renda e a gestáo do orçamento entre as camadas populares sempre envolveram diferentes estratégias para fazer o dinheiro render, como a realização de diferentes trabalhos simultâneos e uma verdadeira "economia dos centavos" (Montenegro, 2014). A escassez de capital entre os pobres se reflete, entre outros aspectos, na importância assumida por operaçóes de pequenos valores, ou ainda em toda uma "economia dos centavos" presente especialmente nos bairros pobres e populosos das grandes cidades, revelando-nos o quanto pode "render" o dinheiro entre a população de baixa renda, tanto para o desenvolvimento de pequenas atividades quanto para a realização de seus consumos diários. Segundo Zaluar (2000, p. 93), entre as famílias pobres que vivem nas periferias das grandes cidades, "são inúmeros os arranjos internos à unidade doméstica para manter o padrão de vida que separa a miséria da pobreza e afasta o espectro da fome”. Diferentes estratégias de obtenção de renda se combinam, com efeito, para manter um padrão mínimo de consumo entre as famílias pobres: multiplicidade de ocupaçôes, realização de 
pequenos "bicos", instalação de vendinhas na própria residência, fabricação de produtos caseiros, diversificação das tarefas no pequeno negócio familiar (Montenegro, 2014).

A subordinação das camadas de baixa renda aos novos nexos financeiros vem implicando, contudo, a emergência de práticas mais "financeirizadas" para fazer o dinheiro render, tais como o recurso ao parcelamento das compras no cartáo de crédito ou ao adiamento do pagamento da fatura para os meses seguintes. Se o parcelamento de compras no carnê já representava um facilitador do consumo, com a proliferação dos cartôes, o parcelamento e a expansão da possibilidade de pagamento a prazo tendem a dinamizar ainda mais a aquisição de bens, cujo valor à vista não caberia no orçamento (Sciré, 2011). No entanto, o que acaba por ocorrer é que grande parte da população gasta, muitas vezes, mais do que ganha, e no momento de pagar as faturas de seus cartôes, não paga o valor integral da fatura, e sim apenas o mínimo exigido para o que cartão seja "liberado" e este possa continuar a ser usado. Tal prática implica, porém, o pagamento de juros extras, o que acaba por multiplicar o valor final das faturas. Trata-se da utilização do crédito rotativo, que possibilita pagar apenas a parcela mínima exigida pela fatura e deixar o restante para o mês seguinte, acrescido de juros, chamados "encargos contratuais", ou ainda realizar saques no cartáo. A disponibilidade de um valor fictício suplementar todo mês leva muitas famílias a considerar o limite dos cartóes de crédito como parte prévia do orçamento, ao qual já é acrescido de antemáo esta renda "extra". O recurso ao crédito rotativo acaba, porém, por revelar-se uma armadilha, cuja lógica perversa dos altos juros dificulta ainda mais a chance de solvência. $\mathrm{O}$ desconhecimento, ou ainda, a não compreensão dos princípios financeiros envolvidos em compras parceladas a juros e na aquisição de empréstimos nos remete à discussão sobre a chamada financial literacy (Clark, 2014), ou ainda às habilidades requeridas para lidar com a crescente complexidade financeira que permeia a vida social em um contexto de recuo dos sistemas de proteção social (Storper, 2014). Nesta direçáo, vale destacar que quase metade dos brasileiros endividados no rotativo do cartão de crédito tem renda mensal inferior a 3 salários mínimos, dentre os quais a inadimplência alcança $47 \%$ (всв, 2015).

Daí a importância da posse de diferentes cartôes de crédito entre este estrato da população. Se um cartão encontra-se cheio de despesas, paga-se apenas o exigido em determinado mês e busca-se não utilizá-lo mais nos meses seguintes. Neste intervalo de tempo, utiliza-se outros cartôes, até que o cartão anterior esteja "desbloqueado", conforme constatamos em entrevistas. Outra prática financeira difundida recentemente, envolvida nesta "ginástica" do orçamento doméstico, reside no empréstimo de cartóes de crédito ou do próprio nome a parentes, amigos e vizinhos. $\mathrm{O}$ estrato de baixa renda é aquele que mais se vale de sua rede social como fonte de auxílio financeiro: 25,5 milhôes de brasileiros emprestaram seu cartão de crédito para parentes ou amigos em 2012 (ABECS, 2012). Entre os entrevistados na periferia paulistana, $40 \%$ declararam já ter usado cartóes de terceiros e $42 \%$ já ter emprestado cartóes a amigos ou parentes. O empréstimo de cartôes envolve a mobilização de vínculos próximos para o auxílio cotidiano, explicitando a importância das redes de apoio social entre indivíduos em situação de pobreza, assentadas, em sua maioria, 
no localismo e na proximidade (Marques, 2010). Emergem, assim, novas formas de coesão social (Aguilar e López Guerrero, 2016), ou ainda, novas formas de sociabilidade em determinados círculos de convívio regular e cotidiano (Frúgoli, 2007) derivadas do avanço da financeirização.

A capilarização dos nexos financeiros pela periferia de São Paulo tem provocado diferentes implicaçóes no território e na vida social como um todo. A expansão da topologia das grandes redes de varejo potencializa a expansão da sociedade de consumo e da lógica de mercado para novos territórios, provocando, para além da fragilidade financeira, a emergência de novas formas de sociabilidade, subjetivação e construção de identidades (Telles, 2010).

A expansão da oferta de crédito, a diversificação da topologia das redes do circuito superior e as consequentes transformaçóes das práticas de consumo entre a população de baixa renda configuram, finalmente, expressóes de um processo mais amplo de avanço de oligopolização não apenas do mercado, mas do próprio território, na medida em que a divisão territorial do trabalho moderna e hegemônica avança sobre as demais divisôes territoriais do trabalho. A conformação de novas situaçóes de oligopólio se refletem, assim, em uma nova ordem espacial, ou seja, em uma mudança da configuração territorial e da própria vida de relaçóes da cidade (Silveira, 2016). Estes processos tendem a tornar os territórios mais instáveis e vulneráveis (Arroyo, 2006), uma vez que mercado e território se confundem (Santos, 1996). Conforme afirma Silveira (2011, p. 45), a própria cidade é, hoje, "uma manifestação da economia oligopolista e um meio para oligopolizaçáo da economia”.

\section{Consideraçóes finais}

Enquanto um fenômeno de profunda dimensão espacial (French, 2011), a financeirização se completa hoje em novas escalas, capilarizando-se pelas diferentes porçôes do território e pela totalidade do corpo social. Esta financeirização, segundo Daher (2016, p. 215), é uma das principais causas de perda de "benefícios sociais e de emergência de pobrezas inéditas, rurais e urbanas, centrais e periféricas", sobretudo em países "em desenvolvimento".

A financeirização implica, por fim, a reprodução de paradoxos característicos do período. Se por um lado, consolida-se como uma estratégia neoliberal de garantia de renovação da demanda, afirma-se, por outro lado, como instrumento de empobrecimento e expropriação. A multiplicação dos canais financeiros de extração da poupança popular corresponde, nesta direção, a um verdadeiro processo de "expropriação financeira" (Lapavitsas, 2011). Assentada na natureza predatória das relaçóes contemporâneas entre instituiçóes financeiras e trabalhadores, a expropriação financeira materializa a possibilidade da realização de lucros crescentes para além da esfera dos salários enquanto um fenômeno social sistemático. Como coloca Ribeiro (2011, p. 23), os desígnios da hegemonia do capital financeiro "atravessam muros físicos e simbólicos, ambientes favoráveis ou adversos, descobrindo renovadas fontes de lucro e propiciando a concentração da riqueza”.

Agentes altamente capitalizados do circuito superior da economia -de origem global, nacional ou metropolitana- se instalam, hoje, nos diferentes níveis da rede 
urbana, mas também em parcelas menos valorizadas do tecido urbano de grandes metrópoles como São Paulo. Essa diversificação de topologia envolve, como vimos, não apenas a aquisição de capitais preexistentes, mas a imposição de formas e instrumentos financeiros e a determinação de novos tipos de consumo e de produção externos ao lugar. Atuando como oligopólios, estas grandes firmas seguem sendo os "agentes determinantes da configuração da economia e do espaço" (Martinelli \& Schoenberger, 1992), provocando transformaçóes locais na estrutura de propriedade das firmas, no consumo, na oferta de crédito, na massa de dinheiro circulante, no grau de monetarização e, por fim, na própria vida de relaçôes (Silveira, 2014). Quebram-se horizontalidades e redefinem-se complementaridades, aprofundando, por conseguinte, a subordinação do circuito inferior em relação ao superior da economia urbana.

Os dinamismos da economia pobre tornam-se hoje crescentemente complexos, haja vista a conformação de um cenário paradoxal em que a expansão do consumo e da financeirização entre as camadas de baixa renda se combina à concentração da pobreza. Variáveis determinantes da globalização, as finanças e o consumo reafirmam-se enquanto variáveis dominantes de nossa época, ao diversificar e sofisticar seus canais de capilaridade pelo tecido social e pelo território.

\section{Referências bibliográficas}

Aalbers, M. B. (2008). The financialization of home and the mortgage market crisis. Competition \&Change, 12, 48-166.

Agência Nacional de Telecomunicaçóes (ANATEL). http://www.anatel.gov.br/dados/

Aguilar, A. \& López Guerrero, F. (2016). Espacios de pobreza en la periferia urbana y suburbios interiores de la Ciudad de México. Las desventajas acumuladas. EURE, 42(125), 5-29. http://www.eure.cl/index.php/eure/article/view/1566/849

Arroyo, M. (2006). A vulnerabilidade dos territórios nacionais: o papel das finanças. Em: Arroyo, M., Lemos, A. I. \& Silveira, M. L. (Eds.). Questōes territoriais na América Latina (pp. 177-190). Buenos Aires: Comisión Latinoamericana de Ciencias Sociales (CLACSO).

Associação Brasileira das Empresas de Cartóes de Crédito e Serviços (ABECS). Indicadores do Mercado. http://www.abecs.org.br/indicadores-de-mercado

Associação Brasileira de Shopping Centers (ABRASCE). Números do Setor. http://abrasce.com. $\mathrm{br} /$ monitoramento

Banco Central do Brasil (всв). (2012). Relatório Anual 2012. http://www.bcb.gov.br/

Banco Central do Brasil (вСв). (2014). Relatório Anual 2014. http://www.bcb.gov.br/

Banco Central do Brasil (вСв). (2015). Relatório Anual 2015. http://www.bcb.gov.br/

Baudrillard, J. (1970). A Sociedade de Consumo. Lisboa: Ediçōes 70.

Bonduki, N. e Rolnik, R. (1979). Periferias: ocupação do espaço e reprodução da força de trabalho. Mimeo. São Paulo: Faculdade de Arquitetura e Urbanismo da Universidade de São Paulo (Fau-usp).

Chesnais, F. (1998). A mundialização do capital. São Paulo: Xamã. 
Chesnais, F. (2005). A Finança mundializada. Raizes sociais e politicas, configuraçōes e consequências. São Paulo: Boitempo.

Christophers, B. (2015). The limits to financialization. Dialogues in human geography, 5(2), 183-200. http://dhg.sagepub.com/content/5/2.toc

Christopherson, S., Martin, R. \& Pollard, J. (2013). Financialisation: roots and repercussions. Cambridge journal of regions, economy and society, (6), 351-357. http://cjres. oxfordjournals.org/content/6/3.toc

Clark, G. (2014). Roepke Lecture in Economic Geography. Financial Literacy in Context. Economic Geography, (90), 1-23. https//doi.10.1111/ecge.12029

Contel, F. B. (2006). Território e finanças. Técnicas, normas e topologias bancárias no Brasil. Tese (Doutorado) - Departamento de Geografia, Faculdade de Filosofia, Letras e Ciências Humanas (FFLCH), Universidade de São Paulo.

Contel, F. B. (2009). Espaço geográfico, sistema bancário e hipercapilaridade do crédito no Brasil. Caderno CRH, (55), 119-134. https//doi.org/10.1590/S0103-49792009000100007

Daher, A. (2016). Externalidades territoriales de la gobernanza financiera global. EURE, 42(126), 213-236. http://www.eure.cl/index.php/eure/article/view|/1523/895

De Mattos, C. (2014). Gobernanza neoliberal, financiarización y metamorfosis urbana en el siglo XXI. CITE/Flacso/Ecuador. http://cite.flacsoandes.edu.ec/media/2016/02/DeMattos-C_2014_Gobernanza-neoliberal financiarizacion-y-metamorfosis-urbana-enel-siglo-XXI.pdf

Dias, L. C. (1992). O sistema financeiro: aceleração dos ritmos econômicos e integração territorial. Anuário do Instituto de Geociência/UfrJ/Río de Janeiro, (15), 43-54. http:// www.ppegeo.igc.usp.br/index.php/anigeo/article/view/1508

Dias, L. C. (2009). Finanças, política e território. Caderno CRH, (55), 9-13. https://doi. org/10.1590/S0103-49792009000100001

Durham, E. R. (2004). A dinâmica cultural. São Paulo: Cosac Naify.

Federaçáo do Comércio de Bens, Serviços e Turismo do Estado de São Paulo (Fecomércio SP). Pesquisa de Endividamento e Inadimplência das Famílias. http://www.fecomercio.com. br/Estudos

French, S., Leyshon, A. \& Wainright, T. (2011). Financializing space, spacing financialization. Progress in human geography, (35), 798-819. http://phg.sagepub.com/content/35/6.toc

Frúgoli, H. (2007). Sociabilidade Urbana. Rio de Janeiro: Jorge Zahar Editora.

Harvey, D. (2011). O enigma do capital e as crises do capitalismo. São Paulo: Boitempo.

Instituto Brasileiro de Geografia e Estatística (IBGE). (2010). Censo Demográfico 2010. http:// www.ibge.gov.br/home/estatistica/populacao/censo2010/default.shtm

Instituto Brasileiro de Geografia e Estatística (IBGE). Pesquisa Nacional de Amostra por Domicílio 2003, 2007, 2009, 2011, 2013. http://www.ibge.gov.br/home/estatistica/populacao/ trabalhoerendimento/pnad2013/default.shtm

Instituto de Pesquisa Econômica Aplicada (IPEA). http://www.ipea.gov.br/portal/

Koulioumba, S. (2002). São Paulo: cidade mundial? Evidências e repostas de uma metrópole em transformação. Tese (Doutorado) - Faculdade de Arquitetura e Urbanismo da Universidade de São Paulo.

Labasse, J. (1976). L'espace financier. Analyse Géographique. Paris: Librairie Armand Colin.

Lapavitsas, C. (2011). Theorizing financialization. Work, employment and society, 25(4) 611626. http://wes.sagepub.com/content/25/4.toc 
Lapavitsas, C. \& Powell, J. (2013). Financialisation varied: a comparative analysis of advanced economies. Cambridge Journal of Regions, Economy and Society, 6, 359-379. https:// doi.org/10.1093/cjres/rst019

Lopes dos Santos, K. (2007). Uma financeirização da pobreza? O sistema financeiro e sua capilaridade no circuito inferior da economia urbana na cidade de São Paulo. Trabalho de Graduação individual. Departamento de Geografia, Faculdade de Filosofia, Letras e Ciências Humanas (FFLCH), Universidade de São Paulo, 2007.

Marques, E. (2010). Redes sociais, segregação e pobreza. Sáo Paulo: Edunesp.

Martinelli, F. \& Schoenberger, E. (1992). Les oligopoles se portent bien, merci! Eléments de réflexion sur l'accumulation flexible. Em G. Benko \& A. Lipietz (Dirs.), Les Régions qui gagnent. Districts et réseaux : les nouveaux paradigmes de la géographie industrielle (pp. 163-188). Paris: Puf.

Miguel, L. M. (2012). A biodiversidade na indústria de cosméticos: contexto internacional e mercado brasileiro. Tese (Doutorado) - Departamento de Geografia FFlch da Universidade de São Paulo.

Montenegro, M. R. (2014). Globalização, trabalho e pobreza no Brasil nas metrópoles brasileiras. São Paulo: Annablume.

Neri, M. (2011). A Nova Classe Média. O lado brilhante da base da pirâmide. São Paulo: Editora Saraiva.

Pochmann, M. (2012). Nova Classe Média? O Trabalho na base da pirâmide social brasileira. São Paulo: Boitempo.

Ribeiro, A. C. T. (2011). Territórios da sociedade: por uma cartografia da ação. Em C. A. da Silva (Ed.), Território e ação social: sentidos da apropriação urbana (pp. 19-34). Rio de Janeiro: Lamparina.

Rocha, S. (2006). Pobreza e indigência no Brasil - algumas evidências empíricas com base na PNAD 2004. Nova Economia, 16(2), 265-299. https://doi.org/10.1590/S010363512006000200003

Rocha, S. (2009). Série de dados e tabulaçōes. Linhas de pobreza e de indigência. Rio de Janeiro: Instituto de Estudos do Trabalho e Sociedade.

Sánchez, J.-E. (2007). Pautas de localización de las sedes de las grandes empresas y entornos metropolitanos. EURE 33(100), 69-90. http://www.eure.cl/index.php/eure/article/ view/1373

Santos, M. (1975). Lespace partagé. Les deux circuits de l'économie urbaine des pays sous-développés. Paris: M.-Th. Génin, Librairies Techniques.

Santos, M. (1996). A natureza do espaço: Técnica e tempo. Razão e emoção. São Paulo: Hucitec.

Santos, M. \& Silveira, M. L. (2001). O Brasil: Território e sociedade no início do século XXI. Rio de Janeiro: Record.

Sciré, C. (2011). Financeirização da pobreza: crédito e endividamento no âmbito das práticas populares de consumo. Teoria \& Pesquisa, (20), 65-78.

Sennet, R. (2006). A cultura do novo capitalismo. São Paulo/Rio de Janeiro: Record.

Silveira, M. L. (2009). Finanças, Consumo e Circuitos da Economia Urbana na Cidade de São Paulo. Caderno CRH, 22(55), 65-76. https://doi.org/10.1590/S010349792009000100004 
Silveira, M. L. (2011). Economia política e ordem espacial: circuitos da economia urbana. Em C. A. da Silva (Ed.). Território e ação social: sentidos da apropriação urbana (pp. 35-51). Rio de Janeiro: Lamparina.

Silveira, M. L. (2014). A natureza relacional dos circuitos da economia urbana. Em F. J. G. Oliveira, D. Mascarenhas \& L. Oliveira (eds.). Geografia Urbana. Ciência e Ação Politica (pp. 155-178). Rio de Janeiro: Consequência.

Silveira, M. L. (Ed.). (2016). Circuitos de la economía urbana: ensayos sobre Buenos Aires y São Paulo. Buenos Aires: Café de las Ciudades.

Sokol, M (2013). Towards a 'newer' economic geography? Injecting finance and financialisation into economic geographies. Cambridge Journal of Regions, Economy and Society, 6(3), 501-515. https//doi.org/10.1093/cjres/rst022

Storper, M. (2014). Commentary on 2013 Roepke Lecture in Economic Geography. Financial Literacy in Context. Economic Geography, 90(1), 25-27. https//doi.10.1111/ ecge. 12030

Telles, V. da S. (2010). A cidade nas fronteiras do legal e do ilegal. Belo Horizonte: Fino Traço.

Torres, H., Bichir, R. M. \& Carpim, T. P. (2006). Uma pobreza diferente? Mudanças no padrão de consumo da população de baixa renda. Novos Estudos Cebrap, (74), 17-22. https:// doi.org/10.1590/S0101-33002006000100002|

Zaluar, A. (2000). A máquina e a Revolta. São Paulo: Brasiliense. 